\title{
Rectal Suspension Dosage Form
}

National Cancer Institute

\section{Source}

National Cancer Institute. Rectal Suspension Dosage Form. NCI Thesaurus. Code C149885.

Liquid preparation consisting of a suspension intended for rectal use or for diagnostic purposes. Rectal suspension are usually presented in containers with a volume in the range of $2.5 \mathrm{~mL}$ to $2000 \mathrm{~mL}$. The container is fitted with an applicator or an applicator is provided separately. 